\title{
Congenital Aphakia
}

National Cancer Institute

\section{Source}

National Cancer Institute. Congenital Aphakia. NCI Thesaurus. Code C35172.

The absence of the lens of the eye that is present at the time of birth. 